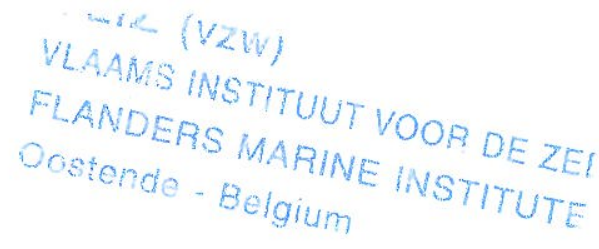

\title{
Lipids and fatty acids in wild and pond-reared mud crab Scylla serrata (Forsskål) during ovarian maturation and spawning
} \author{
Veronica R Alava ${ }^{1}$, Emilia T Quinitio ${ }^{1}$, Jennete B de Pedro ${ }^{1}$, Flora Mae P Priolo,
Zenith Gaye A Orozco ${ }^{1}$ \& Mathieu Wille \\ ${ }^{1}$ Aquaculture Department, Southeast Asian Fisheries Development Center, Buyuan, Tigbauan, Iloilo, Philippines \\ ${ }^{2}$ Laboratory of Aquaculture \& Artemia Reference Center, Ghent University, Ghent, Belgium \\ Correspondence:V R Alava, Aquaculture Department, Southeast Asian Fisheries Development Center,Tigbauan Iloilo 5021, Philippines.
E-mail: vralava@aqd.seafdec.org.ph
}

\begin{abstract}
Wild-caught and pond-reared female mud crab Scylla serrata at different stages of ovarian maturation were collected from Samar and Capiz, Philippines. Crabs were categorized into five stages according to the external morphological and microscopic appearance of the most advanced oocytes. The ovaries, hepatopancreas, muscle and newly spawned eggs (NSE) were analysed for lipid class components and fatty acids. Total lipid was higher in pond-reared than in wildcaught crabs but increased with ovarian maturation in both groups. Ovarian lipid peaked at the fully mature stage, coinciding with a decline in hepatopancreatic and muscle lipids. Lipid levels declined significantly in spent females. The tissues contained elevated highly unsaturated fatty acids such as arachidonic (20:4n-6), eicosapentaenoic (20:5n-3) and docosahexaenoic (22:6n-3) acids, but at higher levels in late maturing and fully mature ovaries and in NSE. The type of lipid class and fatty acid components in mature ovaries as well as in NSE are generally considered to be indicative of their importance in reproductive physiology and embryonic and larval development.
\end{abstract}

Keywords: mud crab, Scylla serrata, ovarian maturation, lipid classes and fatty acids

\section{Introduction}

Mud crab Scylla serrata (Forsskål) inhabits estuaries and mangrove swamps in the Indo-Pacific region and is considered to be one of the most promising crustacean species as an alternative to shrimp aquaculture due to its high value and good growth. Consequently, there is now a large demand for wildcaught mud crab seed for farming that in time may lead to depletion. Although artificial propagation techniques for the species have been established at Southeast Asian Fisheries Development Center Aquaculture Department (SEAFDEC/AQD) (Quinitio \& Parado-Estepa 2003) and broodstock feeds and feeding have been reported (Millamena \& Quinitio 2000; Millamena \& Bangcaya 2001), information on the nutritional factors affecting its ovarian maturation is limited (Li, Lin, Liu \& Wang 1994; Lin \& Wang 1994; Cheng, Li, Wang, Chen, Lin \& Xu 2001). As a first step to elucidate the nutritional requirements of a species, one often looks at what is happening in the wild.

The nutritional status of crustacean broodstock is known to influence significantly the reproductive performance and egg and larval quality (Kanazawa 1981; Harrison 1990; Browdy 1998). Moreover, the reliance of the embryo and newly hatched larvae on the egg yolk for nutrition is essential in understanding the nutrient requirements of broodstock. The biochemical changes in the ovaries and in other tissues will help to determine the importance of nutrient reserves and mobilization during maturation and reproduction.

Lipids play important roles in the biochemistry, metabolism and reproduction of decapod crustaceans. Neutral lipids, particularly triacylglycerols, are a major energy source, and the predominant form of energy storage in the adult, egg and pre-feeding larvae (Middleditch, Missler, Ward, McVey, Brown \& 
Lawrence 1979; Ward, Middleditch, Missler \& Lawrence 1979; Teshima \& Kanazawa 1983; Clarke, Skadsheim \& Holmes 1985). Phospholipids and sterols have important functions as cytoplasm and membrane constituents of cells, affecting structural and physiological properties. Polyunsaturated fatty acids (PUFA) are important components of lipids and are essential for marine fish and crustaceans (Sargent, Tocher \& Bell 2002). Prostaglandins that are involved in the control of many physiological processes have been shown to be derived from PUFA. Ovarian maturation and spawning of penaeid shrimp are influenced by the quality of fatty acids in the diet of Penaeus setiferus (Lawrence, Ward, Missler, Brown, McVey \& Middleditch 1979; Middleditch, Missler, Hines, McVey, Brown, Ward \& Lawrence 1980), P. japonicus (Teshima \& Kanazawa 1983; Teshima, Kanazawa, Horinouchi \& Koshio 1988; Teshima, Kanazawa, Koshio \& Horinouchi 1988; Teshima, Kanazawa, Koshio \& Horinouchi 1989), P. monodon (Millamena 1989; Millamena \& Pascual 1990) and crab (Millamena \& Quinitio 2000).

The aim of this study was to determine the changes in total lipid (TL), lipid class and fatty acid contents in the tissues of wild and pond-reared mud crab S. serrata during ovarian maturation and in newly spawned eggs (NSE) in order to evaluate their significance in crab reproduction.

\section{Materials and methods}

\section{Animals}

Wild-caught and pond-reared female $S$. serrata of various maturation stages were obtained from Samar (eastern Visayas) and Capiz (western Visayas) provinces, Philippines respectively. The identification of S. serrata was based on the description of Keenan, Davie and Mann (1998). The wild crabs fed on detritus and other available natural foods such as sessile in vertebrates (i.e. mollusks) in the mangrove swamps and soft-bottom shallow intertidal waters. Pondreared crabs were taken from a privately owned farm. These were stocked at 2000-3000 ha ${ }^{-1}$ reared for about 5 months with a $40-50 \%$ survival rate. They were fed with low-cost fish and small bivalves Potamocorbula sp. at 8-3\% of the body weight per day (decreasing percentage of body weight as they grow) The feed conversion ratio was about 3.5:1 to 4:1.

Crabs were transported live to SEAFDEC/AQD, Tigbauan, Iloilo, and measured for body weight, internal carapace width and gonadosomatic index and classified into five stages: immature (1), early maturing (2), late maturing (3), fully mature (4) and spent (5) based on external morphological and histological characteristics of the ovaries (Quinitio, de Pedro \& Parado-Estepa 2007). Some females with vitellogenic to late vitellogenic ovaries, as determined by the colour of the ovary between the first abdominal segment and carapace, were held in $12 \mathrm{~m}^{3}$ concrete circular tanks until they spawned. Newly spawned eggs (attached to the pleopods) were collected in addition to the crab ovaries, hepatopancreas and muscle. The spawning tank (height $1.3 \mathrm{~m}$, diameter $4 \mathrm{~m}$ ) had sand and gravel substrates and were provided with wooden shelters. Sand-filtered seawater flowed through for $4 \mathrm{~h}$ daily and water depth was maintained at $25-30 \mathrm{~cm}$. Water temperature fluctuated from 26.5 to $29^{\circ} \mathrm{C}$, while salinity was $31-32 \mathrm{~g} \mathrm{~L}^{-1}$.

\section{TL, lipid class and fatty acid analyses}

Total lipids of samples were extracted after homogenization in chloroform and methanol $(2: 1, \mathrm{v} / \mathrm{v})$ (Folch, Lees \& Sloane-Stanley 1957). For both wild-caught and pond-reared crab tissues, three to 14 females per ovarian stage and four to five NSE were analysed for TL contents. Three TL samples of tissues and zoeae per source of crab and maturation stage were further examined for lipid class and fatty acid contents.

Neutral (NL) and polar lipids (PL) were separated by two solvent systems. The first system, consisting of hexane, diethyl ether and formic acid $98 \%$ (85:15:0.04, v/v), separated the NL classes from PL for $40 \mathrm{~min}$. Individual lipid classes were determined by Thin Layer Chromatography (Iatroscan, MK-5,Tokyo, Japan) with a hydrogen flame ionization detector. After scanning of NL, the same rods with the remaining PL were developed in the second solvent system chloroform-methanol-water $\quad(70: 35: 3.5, \quad \mathrm{v} / \mathrm{v})$ for $45 \mathrm{~min}$ to separate the PL classes, and another scanning of the rods was performed. Identification of lipid classes was carried out by comparison with authentic standard reference mixtures (Nu-Chek-Prep., Elysian, MN, USA).

The preparation of fatty acid methyl esters (FAME) from the TL was carried out using an acetylchloride/ methanol mixture $(1: 20, v / v)$ as the esterification reagent (Lepage \& Roy 1984). The fatty acid compositions were determined using a Chrompack CP9001 gas chromatograph (Macclesfield, UK) equipped with a temperature-programmable on-column injector. Injections were performed into a polar $50 \mathrm{~m}$ capillary 

Table 1 Lipid class contents ( $\mathrm{mg} \mathrm{g}^{-1}$ dry weight) in ovaries and newly spawned eggs (NSE) of wild-caught and pond-reared
mud crab Scylla serrata during ovarian maturation

\begin{tabular}{|c|c|c|c|c|c|c|c|c|c|c|}
\hline & \multicolumn{4}{|l|}{ Source } & \multicolumn{6}{|c|}{ Maturation stage and NSE } \\
\hline & \multicolumn{2}{|l|}{ Ovaries } & \multicolumn{2}{|l|}{ NSE } & \multicolumn{5}{|c|}{ Ovaries } & \multirow[b]{2}{*}{ NSE } \\
\hline & Wild & Pond & Wild & Pond & 1 & 2 & 3 & 4 & 5 & \\
\hline Total lipids & $200.6^{b}$ & $245.5^{\mathrm{a}}$ & $224.3^{\mathrm{b}}$ & $338.7^{\mathrm{a}}$ & $100.5^{t}$ & $211.6^{d}$ & $298.2^{b}$ & $394.0^{\mathrm{a}}$ & $111.0^{\ominus}$ & $281.5^{\circ}$ \\
\hline Total NL & $113.9^{\mathrm{a}}$ & $108.2^{b}$ & $98.5^{b}$ & $137.4^{\mathrm{a}}$ & $31.6^{e}$ & $119.9^{c}$ & $154.4^{b}$ & $192.4^{a}$ & $57.0^{d}$ & $118.0^{\circ}$ \\
\hline $\mathrm{CHO}$ esters & $4.5^{\mathrm{a}}$ & $3.7^{\mathrm{b}}$ & $6.4^{\mathrm{a}}$ & $4.5^{b}$ & $3.3^{\mathrm{b}}$ & $2.5^{b}$ & $2.8^{\mathrm{b}}$ & $5.6^{\mathrm{a}}$ & $6.3^{\mathrm{a}}$ & $5.5^{\mathrm{a}}$ \\
\hline TAG & $94.4^{\mathrm{b}}$ & $102.3^{\mathrm{a}}$ & $61.3^{\mathrm{b}}$ & $126.9^{\mathrm{a}}$ & $0.3^{\theta}$ & $99.7^{c}$ & $135.1^{\mathrm{b}}$ & $169.2^{\mathrm{a}}$ & $36.4^{d}$ & $94.1^{\mathrm{C}}$ \\
\hline FFA & $2.2^{\mathrm{b}}$ & $7.9^{\mathrm{a}}$ & $3.7^{\mathrm{a}}$ & $0.1^{b}$ & $11.1^{\mathrm{a}}$ & $1.7^{c}$ & $1.0^{\circ}$ & $0.1^{d}$ & $3.1^{\mathrm{b}}$ & $3.7^{b}$ \\
\hline $\mathrm{CHO}+\mathrm{DAG}$ & $13.1^{b}$ & $17.3^{\mathrm{a}}$ & $21.9^{\mathrm{a}}$ & $6.0^{\mathrm{b}}$ & $17.2^{\mathrm{a}}$ & $16.1^{a}$ & $16.0^{\mathrm{a}}$ & $17.6^{\mathrm{a}}$ & $9.2^{c}$ & $14.0^{b}$ \\
\hline Total PL & $86.7^{b}$ & $137.3^{\mathrm{a}}$ & $125.8^{b}$ & $201.4^{\mathrm{a}}$ & $68.9^{e}$ & $91.7^{d}$ & $143.8^{c}$ & $201.6^{a}$ & $54.0^{f}$ & $163.6^{b}$ \\
\hline$P E+P A$ & $10.1^{b}$ & $13.7^{\mathrm{a}}$ & $17.9^{\mathrm{a}}$ & $6.1^{b}$ & $16.9^{\mathrm{a}}$ & $10.3^{c}$ & $11.6^{\mathrm{c}}$ & $14.9^{\mathrm{b}}$ & $5.8^{\mathrm{d}}$ & $12.0^{\circ}$ \\
\hline PC & $71.6^{b}$ & $117.6^{\mathrm{a}}$ & $81.3^{\mathrm{b}}$ & $140.6^{\mathrm{a}}$ & $45.0^{e}$ & $77.1^{d}$ & $129.7^{b}$ & $184.3^{\mathrm{a}}$ & $37.1^{t}$ & $111.0^{c}$ \\
\hline SPH & $3.3^{\mathrm{a}}$ & $2.8^{b}$ & $5.1^{\mathrm{a}}$ & $4.5^{\mathrm{b}}$ & $4.5^{\mathrm{a}}$ & $3.8^{\mathrm{b}}$ & $2.2^{c}$ & $1.8^{\mathrm{c}}$ & $2.2^{c}$ & $4.8^{\mathrm{a}}$ \\
\hline LPC & $1.2^{\mathrm{b}}$ & $2.2^{\mathrm{a}}$ & $9.4^{b}$ & $11.7^{\mathrm{a}}$ & $1.9^{b}$ & $0.1^{\circ}$ & $0.8^{\circ}$ & $0.8^{c}$ & $2.0^{6}$ & $10.6^{a}$ \\
\hline
\end{tabular}

Means in the same row with the same superscripts under source of ovaries and NSE or maturation stage and NSE are not significantly
different $(P<0.05)$. Stage 1. immature

NL, neutral lipids; CHO, cholesterol: TAG, triacylging; 4, fully mature; 5, spent ovaries; and NSE, newly spawned eggs.

ethanolamine; PA, phosphatidic acid; PC, phosphatidyl choline; SPH, sphingomyelin

choline.

Table 2 Total lipids ( $\mathrm{mg}^{-1}$ dry weight) in tissues of wild-caught and pond-reared mud crab Scylla serrata during ovarian
maturation and in newly spawned eggs (NSE)

\begin{tabular}{|c|c|c|c|c|c|c|c|c|c|c|c|c|}
\hline \multirow[b]{2}{*}{ Tissues/stage } & \multicolumn{6}{|l|}{ Wild } & \multicolumn{6}{|l|}{ Pond } \\
\hline & 1 & 2 & 3 & 4 & 5 & NSE & 1 & 2 & 3 & 4 & 5 & NSE \\
\hline Ovaries and NSE & $82.7^{t}$ & $181.6^{d}$ & $291.3^{b}$ & $337.8^{a}$ & $109.4^{\theta}$ & $224.3^{\circ}$ & $118.2^{\circ}$ & $241.5^{\mathrm{d}}$ & $305.0^{\circ}$ & $450.2^{\mathrm{a}}$ & $112.5^{\circ}$ & $338.7^{\circ}$ \\
\hline Hepatopancreas & $451.0^{c}$ & $506.2^{b}$ & $542.9^{a}$ & $429.8^{d}$ & $236.0^{\mathrm{e}}$ & & $467.3^{c}$ & $516.1^{\mathrm{b}}$ & $551.5^{\mathrm{a}}$ & $442.7^{d}$ & $368.8^{\mathrm{e}}$ & \\
\hline Muscle & $46.4^{b}$ & $48.6^{a b}$ & $49.9^{a}$ & $47.8^{\mathrm{b}}$ & $39.2^{c}$ & & $42.5^{b}$ & $48.1^{a}$ & $49.1^{\mathrm{a}}$ & $42.6^{b}$ & $36.5^{c}$ & \\
\hline
\end{tabular}

Means in the same row with the same superscripts under wild or pond are not significantly different $(P<0.05)$.
See Table 1 for maturation stages.

column, BPX70 [SGE Analytical Science (Ringwood, Vic., Australia), $50 \mathrm{~m} \times 0.32 \mathrm{~mm}$ ID, $0.25 \mu \mathrm{m}$ film thickness], with a hydrogen flame ionization detector and helium as a carrier. Individual FAME was identified in comparison with authentic standard reference mixtures (Nu-Chek-Prep). Integration and calculations were performed on a computer with a software program MAESTRO (Chrompack).

\section{Statistical analysis}

The lipid contents in tissues and NSE of crabs were quantified as $\mathrm{mg} \mathrm{g}^{-1}$ dry weight and compared using one-way or two-way analysis of variance following a two-factor model [source of crab (wild and pond) as factor 1 and maturation stage as factor 2]; post-test was Duncan's multiple range test (Gomez \& Gomez 1984). Significant level was $P<0.05$.

\section{Results}

\section{TL}

Total lipids in the ovaries correspondingly increased with maturation, but higher levels were found in pond-reared crabs than in wild-caught crabs (Table 1). Total lipids of wild crabs increased fourfold from stages 1 to 4 (82.7-337.8 $\mathrm{mg} \mathrm{g}^{-1}$ ) while those of captive crabs also increased almost fourfold (118.2$450.2 \mathrm{mg} \mathrm{g}^{-1}$ ) (Table 2). After spawning, ovarian TL in wild crab decreased to $109.4 \mathrm{mg} \mathrm{g}^{-1}$ while in captive crabs it declined to $112.5 \mathrm{mg} \mathrm{g}^{-1}$. Total lipids of NSE of captive crabs $\left(338.7 \mathrm{mg} \mathrm{g}^{-1}\right.$ ) was also higher than that of wild crabs $\left(224.3 \mathrm{mg} \mathrm{g}^{-1}\right.$ ) (Table 2).

Total lipids in hepatopancreas of pond-reared crabs was also higher than that of wild crabs (Table 3). These increased from stage 1 until stage 3 (wild: 451.0, 506.2 and 542.9; pond: 467.3, 516.1, $551.5 \mathrm{mg} \mathrm{g}^{-1}$ respectively) and declined at stage 4 

Table 3 Total lipids, neutral (NL) and polar lipid (PL) class contents ( $\mathrm{mg} \mathrm{g}^{-1}$ dry weight) in hepatopancreas and muscle of
wild-caught and pond-reared mud crab Scylla serrata during ovarian maturation

\begin{tabular}{|c|c|c|c|c|c|c|c|}
\hline & \multicolumn{2}{|l|}{ Source } & \multicolumn{5}{|c|}{ Maturation stage } \\
\hline & Wild & Pond & 1 & 2 & 3 & 4 & 5 \\
\hline \multicolumn{8}{|l|}{$\begin{array}{l}\text { Hepatopancreas } \\
\text { Total lipids }\end{array}$} \\
\hline Total lipids & $433.2^{b}$ & $469.3^{a}$ & $459.2^{c}$ & $511.2^{b}$ & $547.2^{\mathrm{a}}$ & $436.3^{d}$ & $302.4^{\theta}$ \\
\hline Total NL & $412.3^{b}$ & $415.5^{a}$ & $366.4^{\mathrm{d}}$ & $476.4^{b}$ & $529.5^{\mathrm{a}}$ & $416.1^{c}$ & $281.3^{\mathrm{\theta}}$ \\
\hline $\mathrm{CHO}$ esters & $23.6^{\mathrm{a}}$ & $13.7^{\mathrm{b}}$ & $25.9^{b}$ & $30.6^{\mathrm{a}}$ & $16.2^{\mathrm{c}}$ & $9.5^{\mathrm{e}}$ & $11.3^{d}$ \\
\hline TAG & $360.3^{a}$ & $316.4^{b}$ & $292.4^{d}$ & $356.7^{c}$ & $428.8^{a}$ & $375.7^{b}$ & $238.2^{\circ}$ \\
\hline FFA & $9.0^{\mathrm{b}}$ & $47.1^{a}$ & $21.4^{\mathrm{c}}$ & $50.7^{\mathrm{a}}$ & $45.6^{b}$ & $11.3^{d}$ & $11.2^{\mathrm{d}}$ \\
\hline $\mathrm{CHO}+\mathrm{DAG}$ & $17.8^{\mathrm{b}}$ & $38.1^{\mathrm{a}}$ & $26.8^{\mathrm{b}}$ & $38.5^{\mathrm{a}}$ & $39.0^{\mathrm{a}}$ & $19.6^{c}$ & $15.8^{d}$ \\
\hline Total PL & $21.0^{\mathrm{b}}$ & $53.7^{\mathrm{a}}$ & $92.7^{a}$ & $34.8^{\mathrm{b}}$ & $17.7^{d}$ & $20.2^{c}$ & $21.5^{c}$ \\
\hline$P E+P A$ & $3.0^{b}$ & $43.7^{\mathrm{a}}$ & $72.3^{a}$ & $60.1^{b}$ & $5.1^{c}$ & $6.2^{\mathrm{c}}$ & $0.6^{d}$ \\
\hline$P C$ & $14.8^{\mathrm{a}}$ & $6.5^{\mathrm{b}}$ & $19.0^{\mathrm{a}}$ & $4.0^{\ominus}$ & $9.6^{c}$ & $13.4^{\mathrm{b}}$ & $7.3^{d}$ \\
\hline LPC & $1.4^{\mathrm{a}}$ & $1.9^{\mathrm{a}}$ & $0.8^{c}$ & $1.4^{\mathrm{b}}$ & $3.1^{\mathrm{a}}$ & $0.7^{\mathrm{c}}$ & $1.8^{\mathrm{b}}$ \\
\hline \multicolumn{8}{|l|}{$\begin{array}{l}\text { Muscle } \\
\text { Total lipids }\end{array}$} \\
\hline Total lipids & $46.4^{\mathrm{a}}$ & $43.8^{\mathrm{b}}$ & $44.5^{b}$ & $48.4^{\mathrm{a}}$ & $49.5^{a}$ & $45.2^{b}$ & $37.9^{c}$ \\
\hline Total NL & $6.9^{\mathrm{a}}$ & $7.0^{\mathrm{a}}$ & $7.0^{\mathrm{b}}$ & $8.4^{\mathrm{a}}$ & $6.9^{\mathrm{b}}$ & $6.5^{\mathrm{b}}$ & $6.0^{\mathrm{b}}$ \\
\hline TAG & $0.5^{\mathrm{a}}$ & $0.2^{\mathrm{a}}$ & $0.2^{a}$ & $0.2^{\mathrm{a}}$ & $0.2^{a}$ & $0.1^{\mathrm{a}}$ & $0.7^{\mathrm{a}}$ \\
\hline FFA & $0.3^{a}$ & $0.7^{\mathrm{a}}$ & $0.7^{\mathrm{a}}$ & $0.8^{a}$ & $0.6^{\mathrm{a}}$ & $0.6^{a}$ & $0.3^{\mathrm{a}}$ \\
\hline $\mathrm{CHO}+\mathrm{DAG}$ & $5.5^{\mathrm{a}}$ & $5.6^{\mathrm{a}}$ & $6.1^{\mathrm{ab}}$ & $7.0^{\mathrm{a}}$ & $5.9^{\mathrm{ab}}$ & $5.1^{\mathrm{b}}$ & $3.9^{\circ}$ \\
\hline Total PL & $39.5^{\mathrm{a}}$ & $36.8^{\mathrm{b}}$ & $37.6^{\mathrm{b}}$ & $39.9^{\mathrm{ab}}$ & $42.6^{a}$ & $38.7^{b}$ & $31.9^{c}$ \\
\hline$P E+P A$ & $3.1^{\mathrm{b}}$ & $8.0^{\mathrm{a}}$ & $6.0^{b}$ & $5.8^{b}$ & $7.1^{\mathrm{a}}$ & $6.3^{\mathrm{b}}$ & $2.7^{c}$ \\
\hline $\mathrm{PC}$ & $22.8^{\mathrm{b}}$ & $26.0^{\mathrm{a}}$ & $26.5^{\mathrm{a}}$ & $26.2^{\mathrm{a}}$ & $25.7^{\mathrm{a}}$ & $25.1^{\mathrm{a}}$ & $18.4^{\mathrm{b}}$ \\
\hline $\mathrm{SPH}$ & $3.7^{\mathrm{a}}$ & $1.5^{\mathrm{b}}$ & $3.3^{\mathrm{a}}$ & $2.9^{\mathrm{a}}$ & $1.4^{b}$ & $2.5^{\mathrm{a}}$ & $3.0^{a}$ \\
\hline LPC & $5.4^{a}$ & $0.8^{\mathrm{b}}$ & $0.5^{\mathrm{c}}$ & $2.7^{b}$ & $5.3^{a}$ & $2.3^{b}$ & $5.0^{\mathrm{a}}$ \\
\hline
\end{tabular}

cantly different $(P<0.05)$. See Table 1 for abbreviations and maturation stages.

(wild: 429.8; pond: $442.7 \mathrm{mg} \mathrm{g}^{-1}$ ) (Table 2). The decrease in TL coincided with the highest lipid content in stage 4 ovaries. After spawning, hepatopancreatic TL reduced significantly, being lower in wild crabs $\left(236.0 \mathrm{mg} \mathrm{g}^{-1}\right)$ than in pond-reared crabs (368.8 $\mathrm{mg} \mathrm{g}^{-1}$ ).

Total lipids in muscle of pond-reared crabs was lower than that of wild crabs (Table 3). Similar to hepatopancreas, muscle TL increased from stages 1 to 3 (wild: 46.4 to 49.9 ; pond: 42.5 to $49.0 \mathrm{mgg}^{-1}$ ) and then declined at stage 4 (wild: 47.8 ; pond: $42.6 \mathrm{mg} \mathrm{g}^{-1}$ ), with a significant decrease at stage 5 (wild: 39.2; pond: $36.5 \mathrm{mg} \mathrm{g}^{-1}$ ) (Table 2).

\section{Lipid classes}

Total neutral lipid and PL in the crab ovaries correspondingly increased during maturation, declined when spent but were found to be high in NSE (Table 1). Ovarian total NL was lower, while the total PL was higher in captive crabs than those of wild crabs. Pondreared crabs produced NSE that contained elevated total NL and total PL compared with those of wild crab NSE.

Wild-caught crab ovaries initially contained higher total PL than total NL, consisting mainly of phosphatidyl choline (PC) and phosphatidyl ethanolamine (PE)+phosphatidic acid (PA) (Table 4). However, a shift occurred at stage 2 when total NL (consisting mainly of triacylglycerols [TAG]) became higher than total PL. Thereafter,TAG significantly increased with maturation until stage 4 . Likewise, PC accumulated and more than doubled at stage 3 and tripled at stage 4. Except for cholesterol (CHO) esters, all other lipid class components in the spent ovaries significantly decreased while these increased in NSE. Total PL was higher than total NL in NSE.

Pond-reared crab ovaries contained more total PL than total NL from stages 1 to 4 (Table 4). After spawning, the ovaries had significantly reduced PC, $\mathrm{PE}+\mathrm{PA}, \mathrm{TAG}$ and $\mathrm{CHO}+$ diacylglycerols (DAG). Their NSE contained a higher total PL than total NL and these were higher than in NSE of wild crabs.

Total NL in hepatopancreas of both wild and captive crabs increased from stage 1 until stage 3 , and 
Table 4 Neutral (NL) and polar lipid (PL) class contents ( $\mathrm{mg} \mathrm{g}^{-1}$ dry weight) in ovaries of wild-caught and pond-reared mud crab Scylla serrata during ovarian maturation and in newly spawned eggs (NSE)

\begin{tabular}{|c|c|c|c|c|c|c|c|c|c|c|c|c|}
\hline \multirow[b]{2}{*}{ Ovaries/stage } & \multicolumn{6}{|l|}{ Wild } & \multicolumn{6}{|l|}{ Pond } \\
\hline & 1 & 2 & 3 & 4 & 5 & NSE & 1 & 2 & 3 & 4 & 5 & NSE \\
\hline Total NL & $23.1^{f}$ & $123.8^{c}$ & $178.2^{b}$ & $189.1^{a}$ & $55.1^{e}$ & $98.5^{\mathrm{d}}$ & $40.1^{e}$ & $115.9^{c}$ & $130.5^{b}$ & $195.6^{\mathrm{a}}$ & $58.8^{d}$ & $137.4^{b}$ \\
\hline $\mathrm{CHO}$ esters & $1.8^{\mathrm{d}}$ & $2.3^{d}$ & $3.3^{c}$ & $5.9^{\mathrm{b}}$ & $9.1^{\mathrm{a}}$ & $6.4^{\mathrm{b}}$ & $4.7^{\mathrm{a}}$ & $2.7^{\mathrm{b}}$ & $2.3^{b}$ & $5.3^{\mathrm{a}}$ & $3.4^{\mathrm{b}}$ & $4.5^{\mathrm{a}}$ \\
\hline TAG & $0.3^{t}$ & $105.9^{c}$ & $162.8^{b}$ & $166.9^{a}$ & $36.1^{\mathrm{e}}$ & $61.3^{d}$ & $0.1^{f}$ & $93.4^{d}$ & $107.4^{c}$ & $171.5^{a}$ & $36.7^{e}$ & $126.9^{b}$ \\
\hline $\mathrm{CHO}+\mathrm{DAG}$ & $16.6^{b}$ & $15.0^{b}$ & $11.2^{c}$ & $16.3^{b}$ & $6.4^{d}$ & $21.9^{\mathrm{a}}$ & $17.7^{\mathrm{b}}$ & $17.1^{b}$ & $20.8^{a}$ & $18.8^{\mathrm{ab}}$ & $11.9^{\circ}$ & $6.0^{d}$ \\
\hline Total PL & $59.6^{d}$ & $57.8^{d}$ & $113.1^{c}$ & $148.7^{\mathrm{a}}$ & $54.3^{\theta}$ & $125.8^{\mathrm{b}}$ & $78.1^{\circ}$ & $125.6^{d}$ & $174.5^{\circ}$ & $254.5^{\mathrm{a}}$ & $53.7^{\prime}$ & $201.4^{\mathrm{b}}$ \\
\hline$P E+P A$ & $12.8^{\mathrm{b}}$ & $9.0^{\mathrm{c}}$ & $12.3^{b}$ & $9.7^{c}$ & $6.5^{\mathrm{d}}$ & $17.9^{\mathrm{a}}$ & $21.0^{\mathrm{a}}$ & $11.5^{\circ}$ & $10.8^{b}$ & $20.1^{a}$ & $5.1^{d}$ & $6.1^{\mathrm{c}}$ \\
\hline PC & $38.8^{d}$ & $43.5^{d}$ & $97.8^{\mathrm{b}}$ & $135.0^{\mathrm{a}}$ & $43.1^{d}$ & $81.3^{c}$ & $51.2^{\theta}$ & $110.7^{d}$ & $161.5^{b}$ & $233.5^{\mathrm{a}}$ & $31.0^{f}$ & $140.6^{\mathrm{c}}$ \\
\hline $\mathrm{SPH}$ & $4.7^{\mathrm{ab}}$ & $4.1^{a b}$ & $2.3^{\mathrm{b}}$ & $2.6^{b}$ & $1.1^{\mathrm{c}}$ & $5.1^{\mathrm{a}}$ & $4.2^{\mathrm{a}}$ & $3.4^{\mathrm{b}}$ & $2.1^{c}$ & $1.0^{d}$ & $3.3^{\mathrm{b}}$ & $4.5^{\mathrm{a}}$ \\
\hline
\end{tabular}

See Table 1 for abbreviations and maturation stages.

decreased at stages 4 and 5 (Table 3). Total NL was higher than total PL in both wild and pond-reared crabs. Both groups had significantly reduced total NL (mainly TAG, CHO+DAG, free fatty acids and $\mathrm{CHO}$ esters) at stages 4 and 5. The polar lipids class contents in both wild and captive crab hepatopancreas were variable during ovarian development.

Total lipids in muscle of wild and captive crabs were dominated by PL that principally contained PC. After spawning, $\mathrm{PC}, \mathrm{PE}+\mathrm{PA}$ and $\mathrm{CHO}+\mathrm{DAG}$ decreased significantly (Table 3).

\section{Fatty acids}

Crab ovaries had increasing total saturated, monoenoic, n-3, n-6 fatty acids (FA) and n-3 highly unsaturated fatty acids (HUFA) with maturation and all these declined significantly in spent ovaries (Table 5). Total n-3 FA was consistently higher than total n-6 FA with a mean n-3/n-6 FA ratio of 1.2 in wild crabs and 1.7 in captive crabs. The major fatty acids were 16:0, 16:1n-7, 18:0, 18:1n-9, 18:1n-7, 20:4n-6 (arachidonic acid, ArA), 20:5n-3 (eicosapentaenoic acid, EPA) and 22:6n-3 (docosahexaenoic acid, DHA), which decreased significantly at the spent stage. The same fatty acids were dominant in the NSE of both crab groups.

Total saturated and monoenoic fatty acids in the hepatopancreas of wild crabs increased until stage 3 while n-3 FA, n-6 FA and n-3 HUFA declined; all drastically decreased after spawning (Table 6). In captive crab hepatopancreas, the saturated, n-3 FA, n-6 FA and n-3 HUFA accumulated until stage 3 while monoenoic FA increased until 4. Except for n-3 FA, all these declined at the spent stage. In wild crabs, dominant FA at stages 3 and 4 that significantly diminished when spent were: 16:0, 16:ln-7, 18:0, $18: 1 n-9, \quad 18: 1 n-7, \quad 18: 2 n-6, \quad 20: 4 n-6, \quad 20: 5 n-3$ and 22:6n-3. Captive crabs also had the same major FA in the hepatopancreas but the total n-3 FA including 20:5n-3 and 22:6n-3 was conserved.

Muscles of wild and captive crabs contained saturated, monoenoic, n-3, n- 6 FA and n-3 HUFA that were variable from stages 1 to 4 , but generally declined at the spent stage (Table 7). Regardless of the source, the trend in the muscle was $20: 5 n-3>20$ : $4 n-6>22: 6 n-3$.

\section{Discussion}

Ovarian TL levels correspondingly increased with maturation and decreased significantly after spawning. Lipids were first stored and then mobilized to the embryo in which higher levels were noted in pondreared than in wild crabs. The hepatopancreas stored a large amount of TL as indicated by the decline at late vitellogenesis and coinciding with the highest lipid content in the ovaries. In general, the lipid levels of ovaries and NSE were higher in captive crabs than wild crabs, indicating that lipid deposits were greatly mobilized in wild crabs. Deposits may have been more limited in wild crabs as levels of several lipid components after spawning were lower in wild crabs. Hepatopancreatic lipids and fatty acids in spent pond-reared crabs were not as low as in the wild ones. Although to a lesser extent, it is clear that muscle lipids were also utilized for maturation based on the decreased levels in the spent stage. This was, however, more significant in wild than in pond-reared crabs, again indicating that wild crabs had to use 

Table 5 Fatty acid contents ( $\mathrm{mg} \mathrm{g}^{-1}$ dry weight) in ovaries and newly spawned eggs (NSE) of wild-caught and pond-reared
mud crab Scylla serrata during ovarian maturation

\begin{tabular}{|c|c|c|c|c|c|c|c|c|c|c|}
\hline \multirow[b]{3}{*}{ FAME } & \multicolumn{4}{|l|}{ Source } & & & & & & \\
\hline & \multicolumn{2}{|l|}{ Ovaries } & \multicolumn{2}{|l|}{ NSE } & \multicolumn{6}{|c|}{ Maturation stage and NSE } \\
\hline & Wild & Pond & Wild & Pond & 1 & 2 & 3 & 4 & 5 & NSE \\
\hline $14: 0$ & $4.7^{\mathrm{b}}$ & $5.5^{\mathrm{a}}$ & $3.2^{\mathrm{b}}$ & $8.1^{a}$ & $1.5^{\mathrm{d}}$ & $5.0^{\mathrm{b}}$ & $5.8^{b}$ & $10.6^{\mathrm{a}}$ & $2.4^{\mathrm{c}}$ & $5.6^{\mathrm{b}}$ \\
\hline $16: 0$ & $37.7^{\mathrm{b}}$ & $44.6^{\mathrm{a}}$ & $37.9^{\mathrm{b}}$ & $65.9^{\mathrm{a}}$ & $13.5^{\mathrm{e}}$ & $40.8^{c}$ & $58.2^{b}$ & $70.8^{a}$ & $22.3^{\mathrm{d}}$ & $51.9^{\mathrm{b}}$ \\
\hline $16: 1 n-7$ & $14.6^{\mathrm{b}}$ & $17.8^{\mathrm{a}}$ & $12.4^{b}$ & $26.4^{a}$ & $5.5^{f}$ & $11.3^{d}$ & $26.2^{\mathrm{b}}$ & $29.4^{\mathrm{a}}$ & $8.7^{\circ}$ & $19.4^{\mathrm{c}}$ \\
\hline $18: 0$ & $14.1^{\mathrm{b}}$ & $19.7^{\mathrm{a}}$ & $22.0^{\mathrm{b}}$ & $33.7^{\mathrm{a}}$ & $7.8^{\circ}$ & $14.7^{d}$ & $20.5^{\circ}$ & $32.9^{\mathrm{a}}$ & $8.6^{8}$ & $27.9^{\circ}$ \\
\hline $18: 1 n-9$ & $27.7^{\mathrm{a}}$ & $27.3^{a}$ & $25.5^{\mathrm{b}}$ & $39.2^{\mathrm{a}}$ & $12.3^{d}$ & $24.4^{\mathrm{c}}$ & $36.0^{\circ}$ & $48.7^{\mathrm{a}}$ & $15.9^{\mathrm{d}}$ & $32.3^{\mathrm{b}}$ \\
\hline $18: 1 n-7$ & $8.7^{\mathrm{a}}$ & $7.7^{\mathrm{b}}$ & $9.0^{\mathrm{b}}$ & $14.6^{\mathrm{a}}$ & $3.3^{d}$ & $7.4^{\mathrm{b}}$ & $11.9^{\mathrm{ab}}$ & $13.0^{\mathrm{a}}$ & $5.4^{c}$ & $11.8^{\mathrm{ab}}$ \\
\hline $18: 2 n-6$ & $6.4^{a}$ & $3.7^{b}$ & $3.0^{b}$ & $5.6^{\mathrm{a}}$ & $1.9^{d}$ & $5.7^{b}$ & $6.1^{\mathrm{b}}$ & $9.7^{\mathrm{a}}$ & $2.0^{d}$ & $4.3^{\mathrm{c}}$ \\
\hline $18: 3 n-3$ & $2.0^{\mathrm{a}}$ & $1.4^{b}$ & $1.1^{b}$ & $1.9^{\mathrm{a}}$ & $0.6^{c}$ & $1.7^{\mathrm{b}}$ & $2.4^{a b}$ & $3.2^{\mathrm{a}}$ & $0.7^{c}$ & $1.5^{\mathrm{b}}$ \\
\hline $20: 1 n-9$ & $1.8^{\mathrm{b}}$ & $2.6^{\mathrm{a}}$ & $1.7^{\mathrm{b}}$ & $2.5^{\mathrm{a}}$ & $1.1^{\circ}$ & $1.8^{\mathrm{bc}}$ & $2.6^{\mathrm{b}}$ & $4.3^{\mathrm{a}}$ & $1.1^{\mathrm{c}}$ & $2.1^{\mathrm{b}}$ \\
\hline $20: 4 n-6$ (ArA) & $15.6^{\mathrm{b}}$ & $18.2^{\mathrm{a}}$ & $19.4^{\mathrm{a}}$ & $17.3^{b}$ & $13.1^{d}$ & $18.6^{\circ}$ & $20.4^{b}$ & $23.8^{a}$ & $8.4^{\mathrm{e}}$ & $18.4^{\mathrm{c}}$ \\
\hline 20:5n-3 (EPA) & $15.2^{b}$ & $20.3^{a}$ & $18.9^{\mathrm{b}}$ & $21.4^{a}$ & $10.6^{c}$ & $19.4^{\mathrm{b}}$ & $19.6^{b}$ & $31.2^{\mathrm{a}}$ & $7.9^{d}$ & $20.2^{b}$ \\
\hline $22: 4 n-6$ & $2.1^{\mathrm{b}}$ & $4.7^{\mathrm{a}}$ & $1.5^{\mathrm{b}}$ & $3.6^{\mathrm{a}}$ & $1.4^{\mathrm{d}}$ & $2.8^{\mathrm{c}}$ & $5.0^{\mathrm{b}}$ & $6.8^{\mathrm{a}}$ & $1.2^{\mathrm{d}}$ & $2.6^{c}$ \\
\hline $22: 5 n-6$ & $2.0^{\mathrm{a}}$ & $2.6^{a}$ & $2.2^{b}$ & $3.6^{\mathrm{a}}$ & $0.9^{c}$ & $2.1^{\mathrm{b}}$ & $3.0^{b}$ & $4.4^{\mathrm{a}}$ & $1.1^{\circ}$ & $2.9^{b}$ \\
\hline $22: 5 n-3$ & $3.8^{\mathrm{b}}$ & $5.7^{\mathrm{a}}$ & $2.7^{\mathrm{b}}$ & $8.4^{\mathrm{a}}$ & $2.1^{d}$ & $5.2^{\mathrm{c}}$ & $6.4^{\mathrm{b}}$ & $8.0^{\mathrm{a}}$ & $2.0^{d}$ & $5.6^{\mathrm{c}}$ \\
\hline $22: 6 n-3(D H A)$ & $15.2^{b}$ & $18.7^{\mathrm{a}}$ & $16.4^{\mathrm{b}}$ & $38.1^{\mathrm{a}}$ & $6.5^{\mathrm{e}}$ & $16.6^{d}$ & $22.3^{\circ}$ & $30.7^{\mathrm{a}}$ & $8.7^{\ominus}$ & $27.3^{b}$ \\
\hline Total lipids & $200.6^{b}$ & $245.5^{a}$ & $224.3^{b}$ & $340.0^{\mathrm{a}}$ & $100.5^{4}$ & $211.6^{d}$ & $298.2^{b}$ & $394.0^{\mathrm{a}}$ & $111.0^{\mathrm{e}}$ & $282.2^{c}$ \\
\hline Sum saturated FA & $62.6^{\mathrm{b}}$ & $77.7^{\mathrm{a}}$ & $69.4^{\mathrm{b}}$ & $119.8^{a}$ & $26.1^{\mathrm{e}}$ & $67.0^{c}$ & $94.1^{\mathrm{b}}$ & $127.2^{\mathrm{a}}$ & $36.4^{d}$ & $94.6^{b}$ \\
\hline Sum monoenoic FA & $59.5^{\mathrm{b}}$ & $64.4^{\mathrm{a}}$ & $59.7^{\mathrm{b}}$ & $100.2^{\mathrm{a}}$ & $26.6^{\circ}$ & $52.6^{\mathrm{C}}$ & $86.7^{b}$ & $107.2^{\mathrm{a}}$ & $36.5^{\mathrm{d}}$ & $79.9^{\mathrm{b}}$ \\
\hline Sum n-3 FA & $38.3^{\mathrm{b}}$ & $47.6^{\mathrm{a}}$ & $41.3^{b}$ & $72.8^{\mathrm{a}}$ & $20.7^{d}$ & $44.5^{c}$ & $52.9^{b}$ & $76.0^{\mathrm{a}}$ & $20.6^{d}$ & $57.1^{\mathrm{b}}$ \\
\hline Sum n-6 FA & $27.1^{\mathrm{b}}$ & $30.2^{\mathrm{a}}$ & $27.2^{\mathrm{b}}$ & $31.9^{\mathrm{a}}$ & $17.5^{d}$ & $29.9^{c}$ & $35.9^{b}$ & $46.7^{\mathrm{a}}$ & $13.3^{d}$ & $29.5^{c}$ \\
\hline Sum n-3 HUFA & $35.5^{\mathrm{b}}$ & $45.5^{\mathrm{a}}$ & $39.0^{\mathrm{b}}$ & $70.5^{\mathrm{a}}$ & $19.7^{\ominus}$ & $42.3^{d}$ & $49.8^{c}$ & $71.4^{\mathrm{a}}$ & $19.2^{\ominus}$ & $54.8^{\mathrm{b}}$ \\
\hline Ratio $n-3 / n-6$ FA & $1.2^{\mathrm{b}}$ & $1.7^{\mathrm{a}}$ & $1.5^{\mathrm{b}}$ & $2.3^{a}$ & $1.2^{\mathrm{b}}$ & $1.5^{\mathrm{b}}$ & $1.7^{\mathrm{ab}}$ & $1.3^{b}$ & $1.7^{\mathrm{ab}}$ & $1.9^{\mathrm{a}}$ \\
\hline Ratio EPA/ArA & $1.0^{\mathrm{a}}$ & $1.1^{\mathrm{a}}$ & $1.0^{\mathrm{a}}$ & $1.2^{\mathrm{a}}$ & $0.8^{a}$ & $1.0^{\mathrm{a}}$ & $1.0^{a}$ & $1.3^{\mathrm{a}}$ & $0.9^{a}$ & $1.1^{\mathrm{a}}$ \\
\hline Ratio DHAVEPA & $1.0^{\mathrm{a}}$ & $0.9^{\mathrm{a}}$ & $1.0^{\mathrm{b}}$ & $1.8^{\mathrm{a}}$ & $0.6^{\mathrm{b}}$ & $0.8^{\mathrm{b}}$ & $1.2^{\mathrm{a}}$ & $1.0^{\mathrm{a}}$ & $1.1^{\mathrm{a}}$ & $1.3^{\mathrm{a}}$ \\
\hline
\end{tabular}

different $(P<0.05)$.

sahexaenoic acid.

their reserves more profoundly. There were no significant differences observed in the histological features between ovaries of wild and pond-reared mud crab $S$ serrata using the same batch of samples (Quinitio et al. 2007). Moreover, GSI was not significantly different between wild and pond-reared females at the different maturation stages, except at stage 4, when GSI of pond-reared crabs was higher. At this stage, the ovarian TL level was higher in pond-reared crabs.

An increase in ovarian lipid corresponding to a decrease in hepatopancreatic lipid was reported in wild S. serrata (Nagabhushanam \& Farooqui 1982). During the peak reproductive periods (May-June and October-November), the lipid contents (and glycogen) decreased in the crab hepatopancreas while an increase in the ovaries was noted. However, no correlation of lipid contents (as well as protein and glycogen) in crab muscles with the reproductive activity was found (Nagabhushanam \& Farooqui 1982). In contrast, lipids in muscles of both wild and pond- reared broodstock decreased after spawning in the present study.

An increase in total ovarian lipids with maturation has also been reported in other wild-sourced crustacean species (Pillay \& Nair 1973; Gehring 1974; Guary, Kayama \& Murakami 1974; Kulkarni \& Nagabhushanam 1979; Read \& Caulton 1980; Galois 1984; Jeckel, de Moreno \& Moreno 1989; Millamena \& Pascual 1990). Several of these authors describe a decrease in the TL of the hepatopancreas, accompanied by an increase in ovarian lipids during maturation, which could be attributed to the mobilization of lipids. While evidence of storage and mobilization of lipids in the hepatopancreas was noted in S. serrata in the present study, the hepatopancreatic lipid reserves could have only partially contributed to vitellogenesis. It appears that dietary lipids must be processed rapidly through the hepatopancreas because the neutral and PL fractions could not fully account for the dramatic increase in ovarian TL. 

Table 6 Fatty acid contents ( $\mathrm{mg} \mathrm{g}^{-1}$ dry weight) in hepatopancreas of wild-caught and pond-reared mud crab Scylla serrata
at different stages of ovarian maturation

\begin{tabular}{|c|c|c|c|c|c|c|c|c|c|c|}
\hline \multirow[b]{2}{*}{ FAME/stage } & \multicolumn{5}{|l|}{ Wild } & \multicolumn{5}{|l|}{ Pond } \\
\hline & 1 & 2 & 3 & 4 & 5 & 1 & 2 & 3 & 4 & 5 \\
\hline $14: 0$ & $12.2^{\circ}$ & $14.5^{\mathrm{b}}$ & $12.9^{c}$ & $25.8^{a}$ & $6.6^{d}$ & $22.4^{\mathrm{a}}$ & $23.3^{a}$ & $23.7^{a}$ & $17.6^{\mathrm{b}}$ & $13.8^{c}$ \\
\hline $15: 0$ & $8.9^{b}$ & $7.7^{\mathrm{c}}$ & $11.4^{\mathrm{a}}$ & $6.8^{\circ}$ & $2.3^{d}$ & $13.3^{\mathrm{a}}$ & $10.4^{\mathrm{b}}$ & $10.5^{\mathrm{b}}$ & $7.6^{c}$ & $6.4^{\mathrm{C}}$ \\
\hline $16: 0$ & $97.8^{\circ}$ & $128.0^{\mathrm{b}}$ & $147.3^{\mathrm{a}}$ & $97.6^{c}$ & $56.5^{d}$ & $132.2^{\mathrm{a}}$ & $132.5^{\mathrm{a}}$ & $131.2^{\mathrm{a}}$ & $103.7^{b}$ & $95.9^{c}$ \\
\hline $16: 1 n-7$ & $26.9^{b}$ & $29.5^{b}$ & $52.4^{\mathrm{a}}$ & $28.6^{\mathrm{b}}$ & $20.3^{c}$ & $38.9^{\mathrm{a}}$ & $36.2^{\mathrm{b}}$ & $37.0^{\mathrm{a}}$ & $35.2^{\mathrm{b}}$ & $27.2^{\mathrm{c}}$ \\
\hline 17:0 & $10.5^{\mathrm{b}}$ & $10.1^{\mathrm{b}}$ & $11.7^{\mathrm{a}}$ & $6.8^{\mathrm{c}}$ & $3.2^{d}$ & $11.1^{\mathrm{a}}$ & $11.4^{\mathrm{a}}$ & $11.3^{\mathrm{a}}$ & $8.9^{b}$ & $8.7^{\mathrm{b}}$ \\
\hline 18:0 & $39.7^{\mathrm{ab}}$ & $42.6^{a}$ & $42.9^{a}$ & $37.3^{\mathrm{b}}$ & $28.0^{\circ}$ & $45.8^{\mathrm{b}}$ & $50.6^{a}$ & $51.4^{a}$ & $39.8^{c}$ & $30.2^{d}$ \\
\hline $18: 1 n-9$ & $31.8^{\circ}$ & $38.6^{\mathrm{b}}$ & $59.2^{\mathrm{a}}$ & $59.9^{\mathrm{a}}$ & $29.3^{d}$ & $34.8^{\mathrm{b}}$ & $34.6^{\mathrm{b}}$ & $36.1^{a}$ & $29.6^{\circ}$ & $34.4^{b}$ \\
\hline $18: 1 n-7$ & $21.0^{\mathrm{c}}$ & $25.6^{\mathrm{b}}$ & $34.9^{\mathrm{a}}$ & $16.4^{d}$ & $12.1^{\theta}$ & $13.2^{\mathrm{c}}$ & $14.7^{\circ}$ & $17.6^{\mathrm{b}}$ & $18.2^{\mathrm{ab}}$ & $19.5^{\mathrm{a}}$ \\
\hline $18: 2 n-6$ & $12.2^{c}$ & $25.1^{a}$ & $14.6^{\mathrm{c}}$ & $17.3^{b}$ & $3.0^{\mathrm{d}}$ & $7.6^{b}$ & $7.1^{\mathrm{b}}$ & $7.6^{\mathrm{b}}$ & $6.8^{b}$ & $9.7^{\mathrm{a}}$ \\
\hline $18: 3 n-3$ & $5.6^{\mathrm{b}}$ & $7.6^{\mathrm{a}}$ & $4.6^{\mathrm{b}}$ & $5.2^{\mathrm{b}}$ & $0.6^{c}$ & $2.2^{b}$ & $2.9^{b}$ & $3.5^{\mathrm{a}}$ & $2.7^{\mathrm{b}}$ & $3.7^{\mathrm{a}}$ \\
\hline $20: 1 n-9$ & $2.9^{\mathrm{b}}$ & $3.9^{\mathrm{ab}}$ & $4.8^{a}$ & $4.7^{a}$ & $2.3^{\mathrm{b}}$ & $5.5^{d}$ & $7.1^{\mathrm{c}}$ & $8.0^{b}$ & $21.3^{\mathrm{a}}$ & $8.5^{b}$ \\
\hline $20: 1 n-7$ & $4.3^{b c}$ & $5.3^{b}$ & $19.0^{\mathrm{a}}$ & $3.6^{c}$ & $2.2^{d}$ & $3.4^{\mathrm{b}}$ & $4.1^{\mathrm{b}}$ & $4.8^{\mathrm{b}}$ & $6.9^{\mathrm{a}}$ & $4.3^{b}$ \\
\hline $20: 4 n-6(\operatorname{ArA})$ & $36.6^{a}$ & $34.0^{\mathrm{b}}$ & $21.0^{\mathrm{c}}$ & $18.1^{d}$ & $6.0^{\circ}$ & $14.2^{d}$ & $20.6^{\mathrm{b}}$ & $25.0^{a}$ & $15.4^{\mathrm{c}}$ & $14.2^{d}$ \\
\hline $20: 5 n-3$ (EPA) & $25.1^{\mathrm{a}}$ & $19.6^{\mathrm{b}}$ & $8.2^{c}$ & $18.3^{b}$ & $3.0^{\mathrm{d}}$ & $13.2^{d}$ & $19.1^{\mathrm{b}}$ & $29.7^{\mathrm{a}}$ & $17.4^{c}$ & $18.6^{\mathrm{bc}}$ \\
\hline $22: 4 n-6$ & $7.1^{\mathrm{b}}$ & $11.9^{\mathrm{a}}$ & $7.9^{b}$ & $3.4^{\mathrm{C}}$ & $0.7^{d}$ & $4.5^{\mathrm{c}}$ & $8.4^{\mathrm{b}}$ & $10.5^{\mathrm{a}}$ & $10.5^{a}$ & $5.8^{c}$ \\
\hline $22: 5 n-6$ & $5.0^{\mathrm{a}}$ & $4.4^{\mathrm{ab}}$ & $3.0^{\mathrm{b}}$ & $4.2^{\mathrm{ab}}$ & $0.7^{c}$ & $2.3^{c}$ & $4.0^{b}$ & $6.0^{\mathrm{a}}$ & $3.6^{\mathrm{bc}}$ & $3.0^{c}$ \\
\hline $22: 5 n-3$ & $8.0^{\mathrm{a}}$ & $8.5^{\mathrm{a}}$ & $4.9^{\mathrm{b}}$ & $4.5^{\mathrm{b}}$ & $1.0^{c}$ & $3.2^{c}$ & $5.1^{c}$ & $7.6^{a}$ & $5.5^{\mathrm{b}}$ & $6.1^{b}$ \\
\hline 22:6n-3 (DHA) & $20.5^{\mathrm{a}}$ & $10.4^{c}$ & $12.0^{\mathrm{b}}$ & $20.8^{\mathrm{a}}$ & $4.0^{d}$ & $11.0^{d}$ & $16.2^{b}$ & $25.8^{\mathrm{a}}$ & $13.5^{c}$ & $15.7^{b}$ \\
\hline Sum saturated FA & $176.3^{d}$ & $215.2^{b}$ & $233.8^{a}$ & $183.1^{c}$ & $109.1^{e}$ & $230.5^{\mathrm{b}}$ & $235.9^{\mathrm{ab}}$ & $237.6^{\mathrm{a}}$ & $186.3^{c}$ & $161.5^{d}$ \\
\hline Sum monoenoic FA & $101.6^{d}$ & $117.2^{\mathrm{c}}$ & $192.9^{a}$ & $125.2^{b}$ & $75.5^{\mathrm{e}}$ & $109.1^{c}$ & $112.2^{b}$ & $120.5^{\mathrm{ab}}$ & $123.8^{a}$ & $105.5^{c}$ \\
\hline Sum n-3 FA & $66.7^{\mathrm{a}}$ & $56.6^{\mathrm{b}}$ & $37.7^{\mathrm{c}}$ & $54.9^{b}$ & $9.2^{d}$ & $33.7^{d}$ & $49.1^{b}$ & $73.5^{\mathrm{a}}$ & $44.7^{\circ}$ & $49.1^{\mathrm{b}}$ \\
\hline Sum n-6 FA & $64.7^{\mathrm{b}}$ & $80.2^{a}$ & $51.7^{c}$ & $45.7^{d}$ & $11.6^{\circ}$ & $32.1^{\mathrm{c}}$ & $44.4^{b}$ & $54.3^{\mathrm{a}}$ & $40.4^{b}$ & $35.9^{c}$ \\
\hline Sum n-3 HUFA & $57.2^{\mathrm{a}}$ & $43.0^{\mathrm{b}}$ & $29.5^{c}$ & $46.1^{\mathrm{b}}$ & $8.5^{d}$ & $30.8^{d}$ & $45.0^{\mathrm{b}}$ & $68.3^{a}$ & $40.8^{c}$ & $44.0^{b}$ \\
\hline Ratio n-3/n-6 FA & $1.0^{\mathrm{a}}$ & $0.7^{a}$ & $0.7^{\mathrm{a}}$ & $1.2^{\mathrm{a}}$ & $0.8^{\mathrm{a}}$ & $1.1^{\mathrm{a}}$ & $1.1^{\mathrm{a}}$ & $1.4^{\mathrm{a}}$ & $1.1^{a}$ & $1.4^{\mathrm{a}}$ \\
\hline Ratio EPAVArA & $0.7^{\mathrm{a}}$ & $0.6^{\mathrm{a}}$ & $0.4^{a}$ & $1.0^{\mathrm{a}}$ & $0.5^{\mathrm{a}}$ & $0.9^{\mathrm{a}}$ & $0.9^{\mathrm{a}}$ & $1.2^{\mathrm{a}}$ & $1.1^{\mathrm{a}}$ & $1.3^{\mathrm{a}}$ \\
\hline Ratio DHAVEPA & $0.8^{\mathrm{b}}$ & $0.5^{b}$ & $1.5^{\mathrm{a}}$ & $1.1^{\mathrm{a}}$ & $1.3^{\mathrm{a}}$ & $0.8^{\mathrm{a}}$ & $0.8^{\mathrm{a}}$ & $0.9^{\mathrm{a}}$ & $0.8^{\mathrm{a}}$ & $0.8^{\mathrm{a}}$ \\
\hline
\end{tabular}

Means with the same superscripts in the same row under wild-caught and pond-reared are not significantly different $(P<0.05)$.

docosahexaenoic acid.

Dietary input to oocyte lipid accumulation was reported in shrimp Penaeus indicus (Galois 1984) and that lipids ingested during vitellogenesis influence the fatty acid composition of haemolymph and egg lipids (Harrison 1990). Radiotracer studies have demonstrated that dietary TAG appear to be sequestered to the developing oocytes within $24 \mathrm{~h}$ of ingestion (Teshima, Kanazawa, Horinouchi et al. 1988; Teshima, Kanazawa, Koshio et al. 1988). Neutral lipids, particularly TAG, were found to be dominant in the hepatopancreas of both wild and pond-reared crabs, confirming its role as a storage organ.

Pond-reared crabs contained higher lipids than wild crabs, probably because food is more readily available all throughout the culture period compared with wild crabs that might have to spend energy constantly in search for food. In the wild, natural foods of Scylla spp. consist of a variety of mollusks and crustaceans (Heasman \& Fielder 1978; Williams 1978; Jayamanne \& Jinadasa 1991). The quantity and quality of the food might have influenced the lipid profiles of crab tissues as well as the degree of mobilization from the hepatopancreas to the ovaries. Lipid accumulation in ovaries and hepatopancreas was higher in pond-reared crabs than in wild crabs.

The influence of dietary input on lipid build-up was reflected in the phospholipids (PL) in crab ovaries. These were present in relatively large amounts throughout the maturation stages of pond-reared crabs but accrued highly only at stages 3 and 4 in wild crabs. Consequently, phospholipids in NSE of pond-reared crabs were higher than in wild crabs. Phospholipids are required for gonadal development of $P$. japonicus (Alava, Kanazawa, Teshima \& Koshio 1993) and reproduction of $P$. vannamei (Cahu, Guillaume, Stephan \& Chim 1994).

In crustaceans, total ovarian sterols are known to increase with maturation (Gehring 1974; Lautier \& Lagarrigue 1988) and may comprise $6.4-22 \%$ of the total ovarian lipids (Teshima \& Kanazawa 1983). In 
Table 7 Fatty acid contents $\left(\mathrm{mg} \mathrm{g}^{-1}\right.$ dry weight) in muscle of wild-caught and pond-reared mud crab Scylla serrata at differ-
ent stages of ovarian

\begin{tabular}{|c|c|c|c|c|c|c|c|c|c|c|}
\hline \multirow[b]{2}{*}{ FAME/stage } & \multicolumn{5}{|l|}{ Wild } & \multicolumn{5}{|l|}{ Pond } \\
\hline & 1 & 2 & 3 & 4 & 5 & 1 & 2 & 3 & 4 & 5 \\
\hline $16: 0$ & $4.9^{a}$ & $5.4^{\mathrm{a}}$ & $5.7^{\mathrm{a}}$ & $5.6^{a}$ & $3.2^{b}$ & $5.0^{\mathrm{b}}$ & $5.7^{b}$ & $6.2^{\mathrm{a}}$ & $5.0^{\mathrm{b}}$ & $4.4^{\mathrm{c}}$ \\
\hline $16: 1 n-7$ & $1.6^{\mathrm{b}}$ & $1.8^{\mathrm{b}}$ & $2.8^{\mathrm{a}}$ & $1.6^{\mathrm{b}}$ & $1.4^{\mathrm{b}}$ & $2.2^{\mathrm{b}}$ & $2.5^{\mathrm{b}}$ & $3.1^{\mathrm{a}}$ & $2.9^{\mathrm{ab}}$ & $1.7^{\circ}$ \\
\hline $18: 0$ & $4.6^{\mathrm{a}}$ & $4.7^{\mathrm{a}}$ & $4.7^{a}$ & $4.7^{\mathrm{a}}$ & $3.3^{\mathrm{b}}$ & $4.0^{\mathrm{a}}$ & $4.5^{\mathrm{a}}$ & $4.5^{a}$ & $4.0^{\mathrm{a}}$ & $2.6^{\mathrm{b}}$ \\
\hline $18: 1 n-9$ & $4.3^{\mathrm{b}}$ & $4.3^{\mathrm{b}}$ & $6.4^{\mathrm{a}}$ & $6.6^{\mathrm{a}}$ & $3.3^{\mathrm{b}}$ & $3.6^{\mathrm{c}}$ & $4.4^{\mathrm{b}}$ & $5.2^{\mathrm{a}}$ & $4.6^{\mathrm{ab}}$ & $3.6^{\mathrm{c}}$ \\
\hline $18: 1 n-7$ & $1.2^{\mathrm{a}}$ & $1.3^{\mathrm{a}}$ & $1.7^{\mathrm{a}}$ & $1.2^{\mathrm{a}}$ & $0.7^{\mathrm{b}}$ & $0.7^{\mathrm{a}}$ & $0.8^{\mathrm{a}}$ & $1.1^{\mathrm{a}}$ & $1.0^{\mathrm{a}}$ & $0.7^{\mathrm{a}}$ \\
\hline $18: 2 n-6$ & $1.5^{\mathrm{a}}$ & $2.4^{\mathrm{a}}$ & $1.9^{\mathrm{a}}$ & $2.0^{\mathrm{a}}$ & $0.6^{\mathrm{b}}$ & $1.0^{a}$ & $1.1^{\mathrm{a}}$ & $0.9^{\mathrm{a}}$ & $1.1^{\mathrm{a}}$ & $1.6^{\mathrm{a}}$ \\
\hline $18: 3 n-3$ & $0.6^{\mathrm{a}}$ & $0.7^{\mathrm{a}}$ & $0.7^{\mathrm{a}}$ & $0.5^{\mathrm{a}}$ & $0.2^{\mathrm{a}}$ & $0.3^{\mathrm{a}}$ & $0.4^{\mathrm{a}}$ & $0.3^{a}$ & $0.3^{\mathrm{a}}$ & $0.6^{a}$ \\
\hline $20: 4 n-6(\operatorname{ArA})$ & $6.5^{\mathrm{b}}$ & $7.3^{\mathrm{a}}$ & $6.9^{\mathrm{ab}}$ & $5.5^{\mathrm{b}}$ & $3.1^{c}$ & $5.1^{\mathrm{a}}$ & $5.8^{\mathrm{a}}$ & $4.9^{\mathrm{ab}}$ & $4.5^{\mathrm{b}}$ & $4.2^{\mathrm{b}}$ \\
\hline 20:5n-3 (EPA) & $8.1^{\mathrm{a}}$ & $8.5^{\mathrm{a}}$ & $7.1^{\mathrm{b}}$ & $8.3^{\mathrm{a}}$ & $4.0^{c}$ & $6.9^{b}$ & $8.0^{a}$ & $7.7^{\mathrm{a}}$ & $6.6^{\mathrm{b}}$ & $5.8^{\circ}$ \\
\hline $22: 4 n-6$ & $0.4^{\mathrm{a}}$ & $0.5^{\mathrm{a}}$ & $0.4^{\mathrm{a}}$ & $0.2^{a}$ & $0.1^{\mathrm{a}}$ & $0.5^{\mathrm{a}}$ & $0.5^{\mathrm{a}}$ & $0.4^{\mathrm{a}}$ & $0.4^{a}$ & $0.3^{\mathrm{a}}$ \\
\hline $22: 5 n-6$ & $0.4^{\mathrm{a}}$ & $0.5^{\mathrm{a}}$ & $0.4^{\mathrm{a}}$ & $0.5^{\mathrm{a}}$ & $0.2^{a}$ & $0.4^{\mathrm{a}}$ & $0.4^{a}$ & $0.5^{\mathrm{a}}$ & $0.4^{\mathrm{a}}$ & $0.3^{\mathrm{a}}$ \\
\hline $22: 5 n-3$ & $0.9^{\mathrm{ab}}$ & $1.3^{\mathrm{a}}$ & $0.5^{\mathrm{b}}$ & $0.4^{\mathrm{b}}$ & $0.2^{\mathrm{b}}$ & $0.9^{\mathrm{a}}$ & $0.9^{\mathrm{a}}$ & $0.9^{a}$ & $0.7^{\mathrm{a}}$ & $0.7^{\mathrm{a}}$ \\
\hline 22:6n-3 (DHA) & $4.7^{\mathrm{a}}$ & $3.8^{b}$ & $4.0^{\mathrm{a}}$ & $4.5^{\mathrm{a}}$ & $2.6^{b}$ & $3.8^{\mathrm{ab}}$ & $4.3^{\mathrm{a}}$ & $4.2^{\mathrm{a}}$ & $3.5^{\mathrm{b}}$ & $3.4^{b}$ \\
\hline Total lipid & $46.4^{b}$ & $48.6^{a}$ & $49.9^{\mathrm{a}}$ & $47.8^{b}$ & $39.2^{c}$ & $42.5^{\mathrm{b}}$ & $48 .^{a}$ & $49.1^{\mathrm{a}}$ & $42.6^{b}$ & $36.5^{c}$ \\
\hline Sum saturated FA & $11.3^{\mathrm{a}}$ & $11.8^{\mathrm{a}}$ & $12.0^{\mathrm{a}}$ & $11.9^{\mathrm{a}}$ & $7.6^{\mathrm{b}}$ & $10.7^{b}$ & $12.0^{a}$ & $12.5^{\mathrm{a}}$ & $10.5^{b}$ & $8.5^{\circ}$ \\
\hline Sum monoenoic FA & $8.0^{b}$ & $8.2^{\mathrm{b}}$ & $11.9^{\mathrm{a}}$ & $10.1^{a}$ & $8.0^{\mathrm{b}}$ & $8.3^{b}$ & $9.8^{\mathrm{ab}}$ & $11.6^{a}$ & $10.7^{a}$ & $8.5^{\mathrm{b}}$ \\
\hline Sum n-3 FA & $14.4^{\mathrm{a}}$ & $14.4^{\mathrm{a}}$ & $12.6^{\mathrm{b}}$ & $14.2^{a}$ & $7.0^{\circ}$ & $12.4^{\mathrm{b}}$ & $14.1^{a}$ & $13.6^{\mathrm{a}}$ & $11.4^{b}$ & $10.7^{\circ}$ \\
\hline Sum n-6 FA & $9.1^{\mathrm{b}}$ & $10.8^{a}$ & $9.9^{\mathrm{ab}}$ & $8.3^{b}$ & $4.0^{c}$ & $7.2^{\mathrm{ab}}$ & $8.0^{a}$ & $6.9^{b}$ & $6.5^{\mathrm{b}}$ & $6.5^{b}$ \\
\hline Sum n-3 HUFA & $13.8^{\mathrm{a}}$ & $13.6^{a}$ & $11.8^{\mathrm{b}}$ & $13.5^{a}$ & $6.8^{\mathrm{c}}$ & $12.0^{b}$ & $13.7^{a}$ & $13.2^{a}$ & $11.0^{\mathrm{b}}$ & $10.1^{c}$ \\
\hline Ratio $n-3 / n-6$ FA & $1.6^{\mathrm{a}}$ & $1.3^{\mathrm{a}}$ & $1.3^{\mathrm{a}}$ & $1.8^{a}$ & $1.8^{\mathrm{a}}$ & $1.7^{\mathrm{a}}$ & $1.8^{\mathrm{a}}$ & $2.0^{a}$ & $1.8^{\mathrm{a}}$ & $1.4^{\mathrm{a}}$ \\
\hline Ratio EPAVArA & $1.2^{\mathrm{a}}$ & $1.2^{\mathrm{a}}$ & $1.0^{a}$ & $1.5^{\mathrm{a}}$ & $1.3^{\mathrm{a}}$ & $1.4^{\mathrm{a}}$ & $1.4^{\mathrm{a}}$ & $1.6^{a}$ & $1.5^{\mathrm{a}}$ & $1.4^{\mathrm{a}}$ \\
\hline Ratio DHA/EPA & $0.6^{\mathrm{a}}$ & $0.4^{\mathrm{a}}$ & $0.6^{a}$ & $0.5^{\mathrm{a}}$ & $0.7^{\mathrm{a}}$ & $0.6^{a}$ & $0.5^{a}$ & $0.5^{\mathrm{a}}$ & $0.5^{a}$ & $0.6^{\mathrm{a}}$ \\
\hline
\end{tabular}

FAME, fatty acid methyl esters; HUFA, highly unsaturated fatty-caught or pond-reared are not significantly different $(P<0.05)$. sahexaenoic acid.

the present study, the increase in ovarian sterols with maturation of $S$. serrata is not evident. Cholesterol esters comprise $1.8-9.1$ in wild crabs and $2.3-5.3$ in pond-reared crabs. Cholesterol was not separated from diacylglycerols $(\mathrm{CHO}+\mathrm{DAG})$. However, a significant decrease was found in spent ovaries, with a corresponding increase in NSE of both wild and pond-reared crabs.

The present study showed that NSE of pond-reared crabs contained n-3 HUFA of $70.5 \mathrm{mg} \mathrm{g}^{-1}$ and an $\mathrm{n} 3 /$ n-6 FA ratio of 2.3, both significantly higher than those of wild-sourced crabs $\left(39.0 \mathrm{mg} \mathrm{g}^{-1}\right.$ and $1.5 \mathrm{re}$ spectively) (Table 5). Newly spawned eggs of wild and pond-sourced S. serrata contain high levels of HUFA such as ArA (20:4n-6), EPA (20:5n-3) and DHA (22:6n-3) with a DHA/EPA ratio of 0.9-1.8 and an EPA/ArA ratio of 1.0-1.2. Based on the present results, broodstock diets were developed to consist of natural food (NF), artificial diets (AD) containing graded TL levels, their combinations $(\mathrm{AD}+\mathrm{NF})$ and fed to pond-sourced broodstock $S$. serrata in tanks (Alava, Quinitio, de Pedro, Orozco \& Wille 2007). The quality of newly hatched zoeae in terms of lipid classes and HUFA concentration was significantly influenced by broodstock diets and 20:4n-6, 20:5n-3 and 22:6n-3 were higher in crabs fed $\mathrm{AD}+\mathrm{NF}$, the contents corresponding to maternal dietary TL levels.

From the combined evidence of high proportions of triacylglycerols, phospholipids, n-6 and n-3 HUFA in ovarian tissues of $S$. serrata and in other crustaceans (Lawrence et al. 1979; Middleditch et al. 1979; Brown Jr, McVey, Scott, Williams, Middleditch \& Lawrence 1980; Teshima \& Kanazawa 1983; Jeckel et al. 1989), the essentiality of these fatty acids to crustaceans (Kanazawa, Teshima, Endo \& Kayama 1978; Kanazawa, Teshima, Tokiwa, Kayama \& Hirata 1979; Kanazawa, Teshima \& Sakamoto 1985), and the indications of the direct influence of dietary fatty acids on the fatty acid contents in the gonads and eggs, the importance of maturation diets high in both n- 6 and n-3 HUFA, cannot be overemphasized.

It is difficult to estimate and quantify the nutritional requirements; however, it is generally accepted that the optimal formulations for broodstock as well as first feeding larvae should simulate the ovaries and egg composition, which somehow reflect the nutrient requirements and metabolic needs of the animals. The study on the lipid classes and fatty acid 
profile of tissues, particularly ovaries and NSE, provides important information for a better understanding on the feeding of broodstock and the first larval stages of $S$. serrata.

\section{Acknowledgments}

This study was funded by the European Union's INCO-DEV project on Culture and Management of the crab Scylla (CAMS, contract ECA4-CT-200110022). The authors would like to thank Mr Quirico J. Ganon, who transported the crabs from Samar and Capiz to SEAFDEC AQD Philippines, and the staff of Laboratory of Aquaculture \& Artemia Reference Center, Ghent University, Belgium, for the lipid class and fatty acid analyses.

\section{References}

Alava V.R., Kanazawa A.,Teshima S. \& Koshio S. (1993) Effect of dietary phospholipids and n-3 highly unsaturated fatty acids on ovarian development of kuruma prawn. Nippon Suisan Gakkaishi 59, 345-351.

Alava V.R., Quinitio E.T., de Pedro J.B., Orozco Z.G.A. \& Wille M. (2007) Reproductive performance, lipids and fatty acids of mud crab Scylla serrata (Forsskål) fed dietary lipid levels. Aquaculture Research 38, 1442-1451.

Browdy C.L. (1998) Recent developments in penaeid broodstock and seed production technologies: improving the outlook for superior captive stocks. Aquaculture 164, 3-22.

Brown A. Jr, McVey J.P., Scott B.M., Williams T.D., Middleditch B.S. \& Lawrence A.L. (1980) The maturation and spawning of Penaeus stylirostris under controlled laboratory conditions. Proceedings of the World Mariculture Society 11, 488-499.

Cahu C., Guillaume J.C., Stephan G. \& Chim L. (1994) Influence of phospholipid and highly unsaturated fatty acids on spawning rate and egg and tissue composition in Penaeus vannamei fed semi-purified diets. Aquaculture 126, 159-170.

Cheng Y.X., Li S.J., Wang G.Z., Chen X.L., Lin Q.W. \& Xu J. (2001) Changes in lipid class and fatty acid composition in the ovaries and hepatopancreas of the mud crab Scylla serrata during the vitellogenesis of the second ovarian maturation. Acta Oceanologica Sinica Haiyang Xuebao 23, 66-77 (in Chinese).

Clarke A., Skadsheim A. \& Holmes L.J. (1985) Lipid biochemistry and reproductive biology in two species of Gammaridae (Crustacea: Amphipoda). Marine Biology 88, 247-263.

Folch J., Lees M. \& Sloane-Stanley G.H. (1957) A simple method for the isolation and purification of total lipids from animal tissues. Journal of Biological Chemistry 226, 497-509.

Galois R.G. (1984) Variations de la composition lipidique tissuelaire au cours de la vitellogense chez la creette Penaeus indicus Milne Edwards. Journal of Experimental Marine Biology and Ecology 84, 155-166.

Gehring W.R. (1974) Maturational changes in the ovarian lipid spectrum of the pink shrimp Penaeus duorarum duorarum Burkenroad. Comparative Biochemistry and Physiology 49, 511-524.

Gomez K.K. \& Gomez A.A. (1984) Statistical Procedures for Agricultural Research. The International Rice Research Institute, Los Baños, Laguna, The Philippines, 294pp.

Guary J.C., Kayama M. \& Murakami Y. (1974) Lipid class distribution and fatty acid composition of prawn, Penaeus japonicus Bate. Bulletin of Japanese Society of Scientific Fisheries 40, 1027-1032.

Harrison K.E. (1990) The role of nutrition on maturation, reproduction and embryonic development of decapod crustaceans: a review. Journal of Shellfish Research 9, 1-28.

Heasman M.P. \& Fielder D.R. (1978) The Mud Crab. Queensland Museum, Queensland, 15pp.

Jayamanne S.C. \& Jinadasa J. (1991) Food and feeding habits of the mud crab Scylla serrata Forsskall inhabiting the Negombo Lagoon in the west coast of Sri Lanka. Vidyodaya Journal Science 3, 61-70.

Jeckel W.H., de Moreno J.E.A. \& Moreno V.J. (1989) Biochemical composition, lipid classes and fatty acids in the ovary of the shrimp Pleoticus mueleri Bate. Comparative Biochemistry and Physiology 92, 271-276.

Kanazawa A. (1981) Penaeid nutrition. In: Proceedings of the Second International Conference in Aquaculture Nutrition: Biochemical and Physiological Approaches to Shellfish Nutrition (ed. by G.D. Pruder, C.J. Langdon \& D.E. Conklin), pp. 87-105. World Mariculture Society, Louisiana State University, Baton Rouge, LO, USA.

Kanazawa A., Teshima S., Endo M. \& Kayama M. (1978) Ef fects of eicosapentaenoic acid on growth and fatty acid composition of the prawn, Penaeus japonicus. Mentoirs of Faculty of Fisheries Kagoshima University 27, 35-40.

Kanazawa A., Teshima S., Tokiwa S., Kayama M. \& Hirata M. (1979) Essential fatty acids in the diet of prawn. II. Effect of docosahexaenoic acid on growth. Bulletin of Japanese Society of Scientific Fisheries 45, 1141-1153.

Kanazawa A., Teshima S. \& Sakamoto M. (1985) Effects of dietary lipids, fatty acids, and phospholipids on growth and survival of prawn (Penaeus japonicus) larvae. Aquaculture 50, 39-49.

Keenan C.P., Davie P.J.P. \& Mann D. (1998) A revision of the genus Scylla de Haan. 1833 (Crustacea: Decapoda: Brachyura: Portunidae). Raffles Bulletin of Zoology 46, 217245.

Kulkarni G.K. \& Nagabhushanam R. (1979) Mobilization of organic reserves during ovarian development in a marine penaeid prawn Parapenaeopsis hardwickii (Miers) (Crustacea, Decapoda, Penaeidea). Aquaculture $\mathbf{1 8}$ 373-377.

LautierJ. \& Lagarrigue G. (1988) Lipid metabolism of the crab Pachygrapsus marmoratus during vitellogenesis. Biochemical Systematics and Ecology 16, 203-212. 
Lawrence A.L., Ward D., Missler S., Brown A., McVey J. \& Middleditch B.S. (1979) Organ indices and biochemical le vels of ova from penaeid shrimp maintained in captivity versus those captured in the wild. Proceedings of World Mariculture Society 10, 453-463.

Lepage G. \& Roy C.C. (1984) Improved recovery of fatty acids through direct esterification without prior extraction and purification. Journal of Lipid Research 25, 1391-1396.

Li F, Lin S., Liu L. \& Wang G.Z. (1994) Studies on lipid classes and fatty acid composition during ovarian development of Scylla serrata. Journal of Xiamen University 33, 109-115 (in Chinese).

Lin F. \& Wang G.Z (1994) Studies on the biochemical composition during ovarian development of mud crab Scylla serrata. Journal of Xiamen University 33, 116-120 (in Chinese).

Middleditch B.S., Missler S.R., Ward D.G., McVey J.P., Brown A. \& Lawrence A.L. (1979) Maturation of penaeid shrimp: dietary fatty acids. Proceedings of World Mariculture Society 10, 472-476.

Middleditch B.S., Missler S.R., Hines H.B., McVey J.P., Brown A., Ward D.G. \& Lawrence A.L. (1980) Metabolic profiles of penaeid shrimp: dietary lipids and ovarian maturation. Journal of Chromatography 195, 359-368.

Millamena O.M. (1989) Effect of fatty acid composition of broodstock diet on tissue fatty acid patterns and egg fertilization and hatching in pond-reared Penaeus monodon. Asian Fisheries Science 2, 127-134.

Millamena O.M. \& Bangcaya J.P. (2001) Reproductive performance and larval quality of pond-raised Scylla serrata females fed various broodstock diets. Asian Fisheries Science 14, 153-159.

Millamena O.M. \& Pascual F.P. (1990) Tissue lipid content and fatty acid composition of Penaeus monodon broodstock from the wild. Journal of World Aquaculture Society 21, 116-121.

Millamena O.M. \& Quinitio E.T. (2000) The effects of diets on reproductive performance on eyestalk ablated and intact mud crab Scylla serrata. Aquaculture 181, 81-90.

Nagabhushanam R. \& Farooqui U.M. (1982) Mobilization of protein, glycogen and lipid during ovarian maturation in marine crab, Scylla serrata Forsskål. Indian Journal of Marine Science 11, 184-186.

Pillay K.K. \& Nair N.B. (1973) Observations on the biochemical changes in gonads and other organs of Uca annulipes,
Portunus pelagicus, and Metapenaeus affinis (Decapoda: Crustacea) during the reproductive cycle. Marine Biology 18, 167-198.

Quinitio E.T. \& Parado-Estepa F.D. (2003) Biology and Hatchery of Mud Crabs Scylla spp. Aquaculture Extension Manual No. 34. Southeast Asian Fisheries Development Center Aquaculture Department, Tigbauan, Iloilo, Philippines, 42pp.

Quinitio E.T., de Pedro J. \& Parado-Estepa F.D. (2007) Ovarian maturation stages of the mud crab Scylla serrata. Aquaculture Research 38, 1434-1441.

Read G.H.L. \& Caulton M.S. (1980) Changes in mass and chemical composition during the molt cycle and ovarian development in immature and mature Penaeus indicus Milne Edwards. Comparative Biochemistry and Physiology 66 431-437.

Sargent J.R., Tocher D.R. \& Bell J.G. (2002) The Lipids. In: Fish Nutrition, 3rd edn, ed. by J.E. Halver \& R.W. Hardy), Elsevier Science, USA pp. 181-257.

Teshima S. \& Kanazawa A. (1983) Variation in lipid composition during the ovarian maturation of the prawn. Bulletin of Japanese Society of Scientific Fisheries 49, 957-962.

Teshima S., Kanazawa A., Horinouchi K. \& Koshio S. (1988) Lipid metabolism in destalked prawn Penaeus japonicus: induced maturation and transfer of lipid reserves to the ovaries. Nippon Suisan Gakkaishi 54, 1123-1129.

Teshima S., Kanazawa A., Koshio S. \& Horinouchi K. (1988) Lipid metabolism in destalked prawn Penaeus japonicus: induced maturation and accumulation of lipids in the ovaries. Nippon Suisan Gakkaishi 54, 1115-1122.

Teshima S., Kanazawa A., Koshio S. \& Horinouchi K. (1989) Lipid metabolism of the prawn Penaeus japonicus during maturation: variation in lipid profiles of the ovary and hepatopancreas. Comparative Biochemistry and Physiology 92, 45-49.

Ward D.G., Middleditch B.S., Missler S.R. \& Lawrence A.L. (1979) Fatty acid changes during larval development of Penaeus setiferus. Proceedings of World Mariculture Society 10, 464-471.

Williams M.J. (1978) Opening of bivalve shells by the mud crab Scylla serrata Forsskål. Australian Journal Marine Freshwater Research 29, 699-702. 